\title{
Paradiplomasi Bandung Menuju Kota Wisata Halal
}

\author{
Windy Dermawan \\ Universitas Padjadjaran
}

\author{
Akim \\ Universitas Padjadjaran \\ Henike Primawanti \\ Universitas Al-Ghifari
}

\begin{abstract}
This research aims to analyze paradiplomacy of Bandung City towards global public in the development of halal tourism. Paradiplomacy becomes important for subnational actors in the development of local resources and the use of foreign resources. Potential areas that have the opportunity to be developed is halal tourism, which is one of the new trends in tourism in the world. The Bandung city is one of the leading regions in the creative economy in West Java that sees this potential and participates in driving regional development through halal tourism. The method in this research is qualitative by collecting data through interviews and documentation studies. This research found that paradiplomacy became one of the instrument of the Bandung city in the utilization of foreign sources through halal tourism. Bandung City Government interacts toward global public by introducing Bandung as one of the destination in halal tourism. The results of this research also show that the paradiplomacy of the Bandung city is carried out through several stages, including introducing halal tourism to the global public, increasing positive appreciation of halal tourism, strengthening relationships with other actors abroad and influencing it by bringing cooperation with other actors.
\end{abstract}

Keywords: Paradiplomacy, Regional foreign relations, Subnational Government, Halal Tourism, Foreign resources

\begin{abstract}
Abstrak
Riset ini bertujuan menganalisis paradiplomasi Kota Bandung terhadap publik global dalam pengembangan wisata halal. Paradiplomasi menjadi penting bagi aktor subnasional di dalam pengembangan sumberdaya daerah dan pemanfaatan sumber-sumber luar negeri. Potensi daerah yang berpeluang dikembangkan yaitu wisata halal yang menjadi salah satu tren baru dalam pariwisata di dunia. Kota Bandung menjadi salah satu daerah unggulan ekonomi kreatif di Jawa Barat yang melihat potensi ini dan berpartisipasi menggerakkan pembangunan daerah melalui wisata halal. Metode dalam riset ini yaitu kualitatif dengan pengumpulan data melalui wawancara dan studi dokumentasi. Riset ini menemukan bahwa paradiplomasi menjadi salah satu instrumen Kota Bandung dalam pemanfaatan sumber-sumber luar negeri melalui wisata halal. Pemerintah Kota Bandung berinteraksi dengan publik global dengan mengenalkan Bandung sebagai salah satu destinasi dalam wisata halal. Hasil riset ini juga menunjukkan bahwa paradiplomasi Kota Bandung dilakukan melalui beberapa tahapan, diantaranya mengenalkan wisata halal kepada publik global, meningkatkan apresiasi positif mengenai wisata halal, mempererat hubungan dengan aktor lain di luar negeri dan mempengaruhinya dengan mendatangkan kerjasama dengan aktor lain.
\end{abstract}

Kata-kata kunci: Paradiplomasi, Hubungan luar negeri daerah, Pemerintah subnasional, Wisata Halal, sumber-sumber luar negeri 


\section{Pendahuluan}

Perkembangan Hubungan Internasional yang dinamis mempengaruhi berkembangnya aktor-aktor yang tidak lagi hanya merupakan aktor negara saja, namun juga dapat berupa aktor non-negara seperti organisasi internasional, perusahaan multinasional dan aktor subnasional. Kompleksitas masalah dalam hubungan internasional mendorong berkiprahnya aktor subnasional yang berperan dalam kegiatan hubungan luar negeri. Kemunculan aktor subnasional ini merupakan salah satu dampak dari adanya kebijakan desentralisasi dan otonomi daerah yang diterapkan oleh suatu negara agar daerah mampu berkiprah dalam hubungan luar negeri dalam upayanya memajukan pembangunan daerah.

Dalam konteks Indonesia, Undang-Undang Nomor 23 Tahun 2014 tentang Pemerintah Daerah menjadi payung hukum sekaligus peluang bagi daerah untuk berkiprah di luar negeri. Sebagai tuntutan dari peraturan tersebut, Kementerian Luar Negeri mengeluarkan peraturan Menteri Luar Negeri Nomor 09/A/KP/XII/2006/01 mengenai Panduan Umum Tata Cara Hubungan dan Kerjasama Luar Negeri oleh Pemerintah Daerah dan Peraturan Menteri Dalam Negeri Nomor 3 Tahun 2008 tentang Pedoman Pelaksanaan Kerjasama Pemerintah Daerah dengan Pihak Luar Negeri. Peraturan-peraturan ini dibuat bukan untuk membatasi peran aktif pemerintah daerah dalam hubungan luar negeri, namun agar peran pemerintah daerah di luar negeri tidak keluar dari koridor kepentingan nasional dan modalitas kebijakan luar negeri Indonesia yang memang sudah diatur di pusat. Peraturan-peraturan di atas sebagai landasan hukum bagi setiap daerah dalam melakukan hubungan luar negerinya. Salah satu yang dapat dilakukan oleh pemerintah daerah adalah dengan melakukan hubungan luar negeri dengan berperan sebagai aktor subnasional (Isnaeni, 2019).

Pemerintah Kota Bandung merupakan salah satu aktor subnasional yang aktif dan menjadi pelopor bagi daerah lain di Indonesia dalam melakukan hubungan luar negeri. Sejak tahun 1960, Bandung telah menjalin kerjasama Sister City dengan Kota Braunschweig di Jerman, dimana kerjasama ini merupakan salah satu bentuk kerjasama tertua di Indonesia (Bagian Kerjasama Kota Bandung, 2019). Selain itu Kota Bandung juga turut aktif dalam mempromosikan potensi daerahnya baik pariwisata, produk kreatif lokal, UMKM, dan budaya ke luar negeri dalam bentuk pameran atau eksibisi seperti Little Bandung yang digagas oleh pemerintah kota Bandung dalam rangka mendukung dan menguatkan daya saing produk lokal Bandung dan mendorong partisipasinya dalam skala global dan turut andil dalam pendapatan daerah (Disdagin Kota Bandung, 2019). Sebagai kota yang memiliki potensi ekonomi kreatif yang unggul, Kota Bandung juga aktif dalam upaya promosi pariwisata ke luar negeri. Hal ini dikarenakan perkembangan industri pariwisata yang prospektif bagi pembangunan daerah.

Dalam mengoptimalan potensi wisata yang dimiliki, Kota Bandung kini menerapkan wisata halal yang menjadi salah satu trend pariwisata yang sedang berkembang di dunia. Hal ini didukung pula oleh amanat dari Kementerian Pariwisata Republik Indonesia kepada Pemerintah Kota 
Bandung yang merupakan salah satu daerah prioritas pengembangan wisata halal. Pada awal tahun 2019, Kota Bandung dinobatkan sebagai salah satu daerah dengan pariwisata halal unggulan di Indonesia setelah sebelumnya pemerintah pusat menjadikan Kota Bandung sebagai salah satu daerah destinasi prioritas wisata halal Indonesia. Dengan potensi wisata yang beranekaragam dan kesenian yang khas, Bandung sejak lama telah menjadi destinasi pariwisata ungggulan (Hafizh, 2019).

Berdasarkan data yang dirilis oleh Pew Research Center, perkembangan wisata halal salah satunya didasari dengan pertumbuhan populasi muslim di dunia yang meningkat setiap tahunnya (Lipka \& Hackett, 2017). Peluang ini kemudian menjadi suatu hal yang menarik bagi banyak negara untuk gencar mengusung wisata halal sebagai daya tarik publik global khususnya wisatawan Muslim dari seluruh dunia.

Pada awal tahun 2019, Mastercard-Crescent Rating merilis laporan hasil studi Global Muslim Travel Index (GMTI) mengenai peringkat destinasi wisata halal populer di dunia. Dalam studi tersebut, Indonesia berhasil menempati peringkat pertama bersamaan dengan Malaysia sebagai destinasi populer di dunia di antara negara-negara lain (Mastercard \& HalalTrip, 2017). Atas keberhasilan yang diraihnya, Kementerian Pariwisata Republik Indonesia semakin mendorong dan mendukung setiap daerah prioritas pariwisata halal untuk semakin menyiapkan diri dalam penyelenggaraan wisata halal.

Sejak tahun 2016, pemerintah Kota Bandung mulai memfokuskan pelayanan pariwisata halal sebagai bentuk strategi baru pada pariwisatanya. Hal ini mengingat kehadiran wisatawan mancanegara yang datang ke Bandung mayoritas berasal dari Malaysia, Brunei Darussalam dan negara kawasan Timur Tengah (Asdhiana, 2015). Kedatangan mereka menjadi salah satu motivasi bagi Pemerintah Kota Bandung untuk semakin menggencarkan pariwisata halalnya. Terutama dalam promosi ke negara lain antara lain seperti dengan mengikuti pameran industri halal dalam acara Malaysia International Halal Showcase (MIHAS) di Kuala Lumpur pada 2019, kemudian dengan mengadakan Familiarization Trip dengan mengundang jurnalis dari Afghanistan untuk datang ke Bandung.

Beberapa studi terdahulu yang relevan dengan tulisan ini. Turisme seringkali dikaitkan dengan bentuk soft power suatu negara dalam konteks gastronomi (makanan) (Hussin, 2018). Studi dari Battour \& Ismail (2016) yang menemukan bahwa wisata halal sebagai bentuk wisata baru yang potensial di masa depan. Samori, Md Salleh, \& Khalid (2016) dan Nurdiansyah (2018) menunjukkan bahwa wisata halal menjadi tren pariwisata baru di negara-negara Asia seperti Malaysia, Thailand dan Jepang. Adam, Iqbal, \& Trihartono (2017) menemukan bahwa turisme atau wisata halal dijadikan sebagai sarana diplomasi gastro, salah satunya diplomasi Jepang ke Indonesia, bahkan Wibyaninggar \& Aminah (2018) dan Deniar \& Effendi (2019) menunjukkan bahwa wisata halal dijadikan sebagai strategi diplomasi dan ekonomi Jepang disandingkan dengan kearifan lokal yang khas dari masyarakat Jepang, sehingga wisata halal membawa implikasi bagi peningkatan ekonomi dan hubungan diplomatik. Dalam konteks Indonesia, Vargas-Sánchez \& Perano (2018) menemukan bahwa potensi Indonesia untuk mengembangkan wisata halal sangat besar dihadapkan 
pada jumlah populasi muslim terbesar di dunia. Fathun (2018) dan Subarkah (2018) menemukan bahwa diplomasi yang dilakukan oleh aktor pemerintah daerah (paradiplomasi) memberikan kontribusi bagi peningkatan kerjasama internasional di dalam sektor pariwisata daerah. Kajiannya difokuskan pada model dan bentuk wisata halal yang dilakukan oleh aktor subnasional. Fathun (2016) menemukan bahwa paradiplomasi menjadi instrumen bagi Pemerintah daerah untuk menjadi menjadi kota dunia melalui tata kelola pemerintahan yang baik (good local governance). Selain aktor subnegara, Fauzi dkk (2018) dan Ivanova \& Khalifa (2019) menemukan terdapatnya peran aktor nonnegara/korporasi (nongovernmental organization) dalam memberi kontribusi bagi pengembangan sektor wisata di suatu negara. Namun demikian, dalam riset Khoiriati dkk (2016), kesuksesan wisata halal di Indonesia masih belum dioptimasi dengan pengembangan lembaga dan infrastruktur turisme yang berorientasi penuh pada wisata halal dengan merujuk pada nilai-nilai islamik.

Berdasarkan studi terdahulu di atas, tulisan mengenai wisata halal banyak dikaji dalam berbagai dimensi. Dalam konteks Hubungan Internasional, wisata halal menjadi bagian dari diplomasi suatu negara. Tulisan mengenai kiprah aktor subnegara dalam hubungan internasional mengenai wisata halal masih terbatas kajiannya, apalagi dikaitkan dengan implementasi paradiplomasi dibandingkan dengan diplomasi publik atau diplomasi gastro. Tulisan ini berupaya untuk mengkaji aspek paradiplomasi Kota Bandung terhadap publik global mengenai wisata halal. Kajian ini tentunya masih terbatas dilakukan oleh para periset sebelumnya, khususnya menyoal kiprah Kota Bandung, sehingga melalui tulisan ini, peneliti berpeluang memberikan kontribusi baru di dalam mengisi keterbatasan riset sebelumnya. Dalam tulisan ini, periset menggunakan konsep paradiplomasi, hubungan luar negeri daerah dalam konteks transgovernmental relations, dan wisata halal. Artikel ini dimulai dengan pendahuluan yang menyajikan adanya penguatan kiprah aktor subnasional dalam hubungan internasional, hirauan ketertarikan pada isu yang diangkat dalam artikel ini dengan memetakan pula studi terdahulu yang relevan sehingga artikel ini mampu menunjukkan kebaruan dari kajian yang telah ada sebelumnya, kemudian bagian mengenai kerangka konseptual, metode riset, hasil dan pembahasan, kemudian simpulan. Berikut dibahas bagian selanjutnya dari kerangka artikel ini.

\section{Kerangka Konseptual}

Keohane dan Nye menunjukkan bahwa keterlibatan aktor subnasional atau pemerintah daerah sebagai bagian dari transgovernmental relations, untuk menunjukkan interaksi langsung antara lembaga/subunit pemerintah dari pemerintah/negara yang berbeda dimana badan-badan bertindak relatif otonom dari kontrol pemerintah pusat. Sementara pola transnational relations merujuk pada interaksi yang melintasi batas-batas negara dengan setidaknya melibatkan sebuah aktor non-negara. Definisi ini dapat digunakan untuk menggambarkan interaksi lintas batas dari pemerintah Kota Bandung sebagai akor subnasional dengan aktor-aktor subnasional dan non-pemerintah di negara lain (Cohn \& Smith, 1996). 
Hubungan luar negeri pemerintah Kota Bandung dalam menjalankan aktivitas transgovernmental dan atau transnational dapat memainkan peranan penting dalam hubungan internasional.

Pemerintah daerah dapat menjalankan fungsi sebagai aktor utama (primary actors) ataupun sebagai aktor perantara (mediating actors) dalam mencapai tujuan paradiplomasinya (Cohn \& Smith, 1996). Sebagai aktor utama adalah ketika pemerintah daerah terlibat langsung dalam hubungan internasional yang memiliki hubungan lintas-batas negara dengan aktor-aktor pemerintah dan swasta di level global. Sebagai aktor antara, ketika Pemerintah daerah mendorong pemerintah pusat untuk melakukan hubungan luar negeri agar dapat memunculkan kebijakan yang bermanfaat bagi kondisi lokal di berbagai bidang seperti perdagangan dan investasi asing. Keberhasilan pemerintah daerah dalam memanfaatkan hubungan saling ketergantungan yang semakin intens dalam sistem internasional ini dapat memberikan keuntungan dengan menarik investasi, perdagangan internasional ataupun turisme. Hal ini dapat dimungkinkan dapat meningkatkan pertumbuhan ekonomi dan pembangunan sekaligus dapat memberikan hasil positif bagi politik domestik pemerintahan daerah tersebut.

Fenomena keterlibatan pemerintah daerah dalam melakukan hubungan internasional seringkali didefinisikan sebagai paradiplomacy atau parallel diplomacy (Lachapelle \& Paquin, 2005). Dengan meningkatnya keterkaitan ekonomi dunia, semakin membuka peluang bagi pemerintah daerah melakukan paradiplomasi untuk memenuhi kebutuhan pembangunan dan pertumbuhan ekonomi (Lachapelle \& Paquin, 2005). Paradiplomasi memiliki tiga tingkatan fokus. Pada tingkat pertama terkait isu ekonomi dalam memenuhi kepentingan daerah untuk untuk menarik investasi asing, memikat perusahaan-perusahaan internasional ke wilayah tersebut dan menargetkan pasar baru untuk ekspor. Pada konteks ini, umumnya paradiplomasi tidak memiliki dimensi politik yang eksplisit (Lecours, 2007).

Pada tingkat kedua, paradiplomasi melibatkan kerjasama yang lebih luas meliputi budaya, pendidikan, teknis, teknologi dan lain-lain dan lebih multidimensional yang tidak hanya terfokus pada keuntungan ekonomi semata (Lecours, 2007). Kegiatan ini meliputi tingkatan yang lebih sederhana seperti pertukaran budaya, pertukaran pelajar hingga yang lebih kompleks dengan pembangunan wilayah perbatasan antardaerah yang berbeda negara. Pada tingkatan ketiga, paradiplomasi terkait permasalahan politik yang biasanya hubungan luar negeri daerah terkait dengan identitas daerah yang dihadapkan pada identitas nasional. Paradiplomasi pada tingkat ini bisa terlihat di negara-negara yang memberikan perlakuan khusus terkait keistimewaan daerahnya, seperti Quebec, Flanders, Catalonia dan the Basque Country.

Ketiga tingkatan paradiplomasi seringkali dilakukan secara simultan dan pada umumnya di beberapa daerah di negara-negara maju dilakukan lebih mengedepankan komponen ekonomi. Namun, tidak menutup kemungkinan untuk bergerak menambahkan komponen yang lebih politis. Dalam hal ini paradiplomasi dapat dilihat sebagai alat 
bagi upaya pencapaian kepentingan daerah yang multi fungsi. Daerah dapat memutuskan melakukan paradiplomasi terhadap negara atau aktor lain di luar negeri untuk mendukung pembangunan daerah dan pertumbuhan ekonomi dan merekapun dapat memasukkan unsur-unsur lain yang berkaitan dengan kepentingan daerah mereka.

Beberapa kepentingan tersebut tidak terbatas pada negara, juga pada aktor-aktor non-negara ketika aktor subnasional berupaya mengembangkan masyarakatnya tidak menutup kemungkinan bagi daerah melakukan kerjasama dengan lembaga-lembaga nirlaba, seperti NGOs. Bahkan, bila pemerintah daerah memerlukan tambahan investasi ekonomi, selain menjalin hubungan luar negeri daerah dengan pemerintahan negara lain, mereka juga dapat melakukan kerjasama dengan perusahaan atau investor asing. Peran paradiplomasi yang dilakukan oleh daerah pada dasarnya merupakan upaya pemerintah daerah untuk mencapai kepentingan daerahnya.

Dalam konteks tulisan ini, paradiplomasi yang dijalankan oleh Pemerintah Kota Bandung mengenai wisata halal dapat dimaknai sebagai upaya Kota Bandung di dalam meningkatkan pembangunan daerah dengan memanfaatkan potensi yang dimilikinya sebagai destinasi wisata halal. Namun demikian, tidak terbatas pada aspek ekonomi semata, terdapat pula aspek nonekonomis yang dibangun yang dilandasi oleh nilai-nilai sosial dan budaya Kota Bandung. Peneliti mengambil perspektif dari Leonard (2002) untuk melihat dimensi akivitas paradiplomasi Kota Bandung, diantaranya yaitu introducing, increasing a positive appreciation, engaging dan influencing. Pada tahap pengenalan (introducing), Pemerintah Kota Bandung membuat dirinya agar dikenal oleh aktor lain. Tahapan selanjutnya yaitu increasing a positive appreciation, yakni ketika publik global telah mengenal keberadaan Kota Bandung dengan citra tertentu, yang dilakukan adalah meningkatkan apresiasi dari publik global kepada Kota Bandung. Tahapan ketiga yakni engaging kepada publik global dengan mempererat dan menambah kedekatan hubungan satu sama lain. Dengan meningkatkan keterikatan ini, suatu aktor subnasional telah memiliki persepsi positif sehingga dianggap sebagai pihak yang penting pada level global. Tahap terakhir ketika pada tahap sebelumnya telah terlaksana yaitu influencing atau mempengaruhi pihak lain. Mempengaruhi tersebut dapat dilakukan karena sebelumnya telah memiliki modal yang kuat dalam melaksanakan paradiplomasi sehingga berusaha meningkatkan intensitas hubungan luar negeri hingga mampu mendatangkan investasi luar negeri ke daerah, perdagangan dan kerjasama di bidang lainnya.

Konsep selanjutnya dalam tulisan ini yaitu wisata halal. Istilah wisata halal yang merujuk pada Battour dan Ismail (2016), sebagai suatu objek atau tindakan dalam pariwisata yang dalam hal ini berdasarkan kepada ajaran atau hukum Islam (syariah) pada aktivitas berkaitan pada industri pariwisata. Adapun istilah halal itu sendiri menurut Al-Qardhawi (2013), yakni segala sesuatu yang diperbolehkan dengan tidak adanya larangan dalam melakukannnya serta adanya syariat yang memperbolehkan. Definisi tersebut kemudian menunjukkan bahwa dalam wisata halal, hukum Islam menjadi dasar dalam memberikan produk dan layanan pariwisata dengan 
sasaran utama wisatawan muslim serta seringkali disebut dengan istilah pariwisata syariah. Wisata halal menjadi pilihan wisatawan dalam aktivitas pariwisata dikarenakan karakteristik dari produk dan layanan yang dibutuhkan tidak bertentangan dengan nilai dan etika yang dipercayai dalam agama Islam serta tidak hanya sebatas pada wisata relijik (Satriana \& Faridah, 2018). Kearifan lokal dapat menjadi potensi yang bernilai jual karena keunikan dan karakter yang dimiliki oleh masing-masing daerah yang dihuni oleh komunitas tertentu, serta mampu mewarnai atraksi wisata yang dikembangkan di daerah destinasi pariwisata (Battour \& Ismail, 2016). Mohsin, Ramli, \& Alkhulayfi (2016) menunjukkan bahwa wisata halal mengacu kepada ketentuan layanan produk dan jasa pariwisata yang bertemu dengan kebutuhan bagi wisatawan muslim dengan memberikan fasilitas untuk ibadah dan kebutuhan makanan yang berlandaskan kepada ajaran Islam. Maka dari itu, wisata halal mengacu kepada jenis wisata yang menganut nilai-nilai Islam pada prakteknya.

Metode yang digunakan pada tulisan ini adalah metode kualitatif dengan pengumpulan data melalui wawancara terhadap sejumlah informan yang relevan, studi pustaka, dan penelusuran daring. Unit analisis dari tulisan ini yaitu paradiplomasi Kota Bandung. Pengumpulan data diperoleh melalui wawancara kepada Bagian Kerjasama Pemerintah Kota Bandung, Kementerian Pariwisata Republik Indonesia, dan sejumlah akademisi paradiplomasi dan wisata halal. Studi kepustakaan dilakukan dengan menggali sejumlah literatur yang relevan dengan tema riset dari berbagai jurnal, laporan, berita daring, dan buku. Penelusuran berita daring yang berkaitan dengan penyelenggaraan paradiplomasi Kota Bandung terkait wisata halal, promosi dan bentuk upaya lainnya yang dilakukan oleh pemangku kepentingan dari wisata halal.

\section{Wisata Halal di Kota Bandung}

Kota Bandung adalah salah satu kota metropolitan di Indonesia serta merupakan ibukota dari Provinsi Jawa Barat. Letak geografis Kota Bandung berada di tengah-tengah Provinsi Jawa Barat yang membuatnya memiliki lokasi yang sangat strategis, dengan ketinggian kurang lebih 768 meter di atas permukaan laut. Letaknya yang dikelilingi oleh pegunungan membuat Bandung terlihat seperti danau atau telaga. Hal ini kemudian membuat Bandung menjadi kota dengan suhu tahunan yang lebih dingin dengan udara yang sejuk dan segar dibandingkan dengan kota-kota metropolitan lainnya di Indonesia (PPID Kota Bandung, 2016). Secara singkat, kata Bandung memiliki arti filosofis sebagai alam tempat tinggal makhluk hidup maupun benda mati yang lahir dan tinggal di Ibu Pertiwi dengan keberadaannya disaksikan oleh Yang Maha Kuasa (PPID Kota Bandung, 2016).

Pada abad ke-18 di era penjajahan Hindia-Belanda, Bandung mulai dijadikan sebagai Kawasan pemukiman serta pembangunan sarana prasarana penunjang lainnya. Selain membangun kebun teh dan perkebunan lainnya, mereka juga menjadikan Bandung sebagai tempat untuk beristirahat dan membangunnya menjadi kota dengan beraneka kota mewah, restoran, kafe-kafe dan serta butik ala Eropa. Mereka 
kemudian menamakan Bandung dengan istilah Parijs van Java yang dilihat sebagai replika dari Kota Paris di Eropa baik dari segi seni, arsitektur serta keanekaragaman fashion yang ada pada Bandung (Jo, 2016).

Kementerian Pariwisata menambah beberapa destinasi prioritas untuk pengembangan pariwisata halal di Indonesia, salah satunya yaitu Kota Bandung. Hal ini karena Kota Bandung dianggap telah layak dan paripurna untuk menjadi daerah destinasi wisata halal. Sejak tahun 2016, pemerintah pusat dan pemerintah kota telah bersinergi dalam mengembangkan wisata halal Bandung. Dengan kelebihan Bandung sebagai kota destinasi wisata sejak dahulu, maka pengembangan wisata halal akan dapat dilakukan lebih mudah dengan kondisi Bandung yang memiliki populasi muslim terbesar (Pratiwi, Dida, \& Sjafirah, 2018).

Pada tahun 2018, Kota Bandung mendapatkan penghargaan sebagai destinasi pariwisata halal terbaik dari Kementerian Pariwisata Republik Indonesia pada acara Wonderful Indonesia Halal Tourism Meeting and Conference. Selain itu pula dalam acara penghargaan tersebut, Pemerintah Kota Bandung menandatangani MoU dengan Kementerian Pariwisata mengenai peningkatan pengembangan wisata halal di Kota Bandung dengan tujuan agar Kota Bandung selalu berkomitmen dalam menyediakan sejumlah fasilitas untuk pariwisata halal (Hafizh, 2019). Dengan adanya pariwisata halal di Kota Bandung maka diharapkan dapat mengakomodir kebutuhan dari wisatawan muslim baik domestik maupun mancanegara serta meningkatnya jumlah kehadiran wisatawan sebesar 10 persen. Kawasan Masjid Raya dan Alun-Alun Bandung selalu menjadi destinasi pariwisata utama di Kota Bandung. Selain karena posisinya yang strategis berada di pusat kota, daerah di sekitar kawasan tersebut yang terdapat destinasi wisata lainnya seperti Museum Konferensi Asia Afrika (KAA), Pusat Perbelanjaan Pasar Baru, Jalan Braga, yang selalu dipadati oleh wisatawan pada akhir pekan. Akses menuju tempat tersebut juga dekat dengan stasiun dan terminal. Wisatawan yang datang dengan mudah menemui tempat untuk sholat serta kebutuhan lainnya dalam berpariwisata. Selain itu, pusat perbelanjaan yang terdapat di sekitar kawasan tersebut menyediakan banyak pakaian muslim, alat sholat serta berbagai kebutuhan lainnya.

Dalam wisata kuliner, model wisata halal menjamin adanya restoranrestoran atau tempat makan yang sudah tersertifikasi halal. Di Indonesia sendiri urusan mengenai sertifikasi halal ditangani oleh Majelis Ulama Indonesia (MUI). Dengan adanya sertifikasi halal maka pengunjung akan merasa terjamin dan aman akan kehalalan makanan yang dikonsumsi. Di Bandung, restoran atau tempat makan halal dapat dengan mudah ditemui dikarenakan pasar yang beragama islam berjumlah sangat besar. Termasuk pula makanan yang merupakan kategori Chinese dan Japanese food yang juga sudah mendapatkan sertifikasi halal. 


\section{Aspek Paralelitas dari Paradiplomasi Kota Bandung mengenai Wisata Halal}

Dalam penyelenggaraan wisata halal di Kota Bandung, sinergitas berbagai aktor di dalamnya menjadi kunci kesuksesan dan langkah yang tepat. Hal ini dikarenakan pemerintah kota Bandung tidak dapat bekerja sendiri saja, butuh pihak-pihak yang juga ikut serta dalam menyukseskan dan bertanggungjawab atas penyelenggaraan wisata halal. Aktor paradiplomasi Kota Bandung tidak hanya unsur Pemerintah Kota yang menjadi leading sector paradiplomasi, namun aktivitas paradiplomasi bergerak secara paralel dengan unsur-unsur aktor nonnegara di Kota Bandung dan menjadi penyokong bagi Pemerintah Kota Bandung yang disebut dengan istilah pentahelix pariwisata yang menjadi kunci dari pengembangan wisata di Indonesia guna mencapai target kunjungan publik global. Unsur dari pentahelix ini terdiri dari aktor-aktor yang ikut menyukseskan pariwisata yang terdiri dari 'ABCGM', yaitu Academician (Akademisi), Business (Pebisnis atau pelaku industri wisata), Community (Masyarakat atau komunitas), Government (Pemerintah pusat dan daerah), dan Media (Media). Lima unsur ini saling mendukung dalam membangun iklim wisata yang kondusif.

Kota Bandung sebagai destinasi wisata halal telah memiliki unsur dari pentahelix tersebut yang sudah memberikan dukungan luas dalam penyelenggaraan wisata halal. Bandung dikenal sebagai kota pendidikan dimana banyak terdapat institusi pendidikan tinggi yang terkenal dengan kualitas yang baik. Akademisi dari institusi pendidikan di Kota Bandung turut mendukung pengembangan wisata halal Kota Bandung. Sekolah Tinggi Pariwisata (STP) Bandung menjadi salah satu aktor pendidikan bidang pariwisata dibawah supervisi Kementerian Pariwisata Indonesia. STP Bandung telah memiliki pusat studi pengkajian wisata dan produk halal yang bernama Enhaii Halal Tourism Center (EHTC) yang ikut andil dalam mengkaji potensi pengembangan wisata halal di Kota Bandung dengan publikasi penelitian yang banyak (Radd, 2016). Terdapat pula Institut Teknologi Bandung (ITB) yang membentuk Pusat Halal Salman-ITB yang hadir untuk mendukung program pemerintah dalam merealisasikan sertifikasi produk halal. ITB menyediakan lembaga untuk penelitian mengenai aspek halal dan keamanan pada suatu produk makanan maupun obat-obat. Terakhir yaitu UIN Sunan Gunung Djati Bandung melalui Fakultas Syariah dan Hukum (FSH) yang menyediakan persiapan sumber daya manusia yang kompeten pada pengembangan pariwisata halal khususnya di Bandung.

Unsur pentahelix yang berasal dari pelaku bisnis atau pegiat industri wisata halal seperti restoran, tempat makan, dan UMKM yang bergerak di industri kreatif. Kota Bandung merupakan salah satu pusat industri kreatif di Indonesia, hal ini menjadi salah satu penggerak perekonomian di Bandung serta mampu menarik wisatawan untuk berbelanja maupun santap kuliner. Pada tahun 2012, Bandung pernah menjadi tuan rumah dari acara World Islamic Economic Forum (WIEF) karena Bandung dapat menjadi model industri kreatif di Indonesia dan dunia. Penginapan atau hotel juga 
menjadi salah satu unsur utama dalam pengembangan wisata halal dengan pelayanan yang mampu memenuhi kebutuhan wisatawan muslim. Dalam industri wisata halal, kebutuhan akan jaminan sertifikasi halal menjadi kunci. Oleh karenanya, pegiat industri halal diharuskan memberi sertifikat halal bagi produk dan jasanya.

Unsur berikutnya yaitu masyarakat maupun komunitas di Kota Bandung yang dikenal agamis dengan menjamurnya komunitas new dakwah movement yang menggerakan para pemuda untuk mengamalkan nilainilai yang islamik. Masyarakat merupakan salah satu aktor utama pada pelaksanaan pariwisata halal dan juga paradiplomasi. Oleh karenanya, masyarakat menjadi aktor yang turut aktif dalam penyelenggaraan wisata halal. Masyarakat harus memiliki kesadaran sejak dini mengenai pentingnya pariwisata halal terutama bagi yang beragama Islam. Dengan kesadaran yang dimiliki, masyarakat akan menjadi selektif untuk memilih makanan yang sudah terjamin kehalalannya, memilih hiburan yang tidak hanya atraktif namun juga edukatif. Agen perjalanan di Kota Bandung juga telah memberikan paket pelayanan wisata halal Kota Bandung mulai dari penginapan, destinasi wisata halal hingga atraksi objek wisata halal.

Peran dari pemerintah pusat dan daerah yang memiliki tugas utama dalam mengatur regulasi wisata halal, mempromosikan, menjajaki kerjasama dengan pihak lain danjuga menyusun pedoman penyelenggaraan wisata halal. Pemerintah Kota Bandung membentuk Tim Percepatan Wisata Halal Kota Bandung dalam rangka mendukung pengembangan wisata halal di Bandung agar semakin baik. Selain itu pula pemerintah melalui Badan Penyelenggara Jaminan Produk Halal (BPJPH) beserta LPPOM-MUI memiliki wewenang dan tugas untuk memberikan sertifikasi halal pada suatu produk maupun layanan wisata. MUI Kota Bandung memberikan dukungan penuh dalam pengembangan wisata halal di Kota Bandung dengan melakukan pengujian pada makanan halal di laboratorium dan memberikan sertifikasi halal bagi pelaku industri. Dukungan Pemerintah Kota Bandung terhadap para pelaku UMKM ditunjukkan dengan akses untuk mengurus sertifikasi halal di Dinas Perdagangan dan Perindustrian Kota Bandung dengan gratis karena dibiayai oleh pemerintah. Pelaku industri halal akan mendapatkan fasilitas layanan berupa bantuan izin label halal, pemeriksaan nutrisi makanan, konsultasi pengemasan hingga hak merek.

Terakhir, unsur media dalam keikutsertaannya memberitakan, meliput dan mempromosikan wisata halal di Kota Bandung. Media massa televisi nasional, NET Tv pada program Indonesia Morning Show pernah meliput wisata halal di Kota Bandung dengan mengenalkan destinasi wisata masjid, wisata belanja busana muslim, hotel syariah dan kuliner halal yang ada di Kota Bandung. Tayangan tersebut juga diunggah kembali pada akun YouTube IMS Net. Selain itu pula, Humas Kota Bandung menayangkan publikasi mengenai penyelenggaraan wisata halal Kota Bandung melalui akun YouTube Humasbdg. Selain melalui media liputan televisi dan platform YouTube, media berita online juga ikut memberitakan mengenai pariwisata halal Kota Bandung. Masyarakat kini sering mengakses berita melalui platform daring sehingga informasi mengenai wisata halal dapat 
diakses dengan baik dan mudah. Masyarakat juga dapat mengakses pemberitaan melalui media sosial mengenai informasi destinasi wisata halal di Kota Bandung.

\section{Paradiplomasi Kota Bandung mengenai Wisata Halal}

Dalam pemaparan bentuk pelaksanaan paradiplomasi Kota Bandung mengenai wisata halal, periset menggunakan perspektif dari Leonard (2002) yang terdiri dari introducing, increasing a positive appreciation, enganging dan influencing. Pada pelaksanaan paradiplomasi aktor subnasional juga memiliki andil pada penyelenggaraan wisata halal sehingga sinergitas yang terjadi pada setiap lembaga mampu menyukseskan pelaksanaan paradiplomasi Kota Bandung pada wisata halal.

Kota Bandung sebelumnya memang telah dikenal oleh negara lain maupun masyarakat Indonesia sendiri sebagai destinasi pariwisita unggulan yang menawarkan beranekaragam potensi pariwisata mulai dari wisata alam, wisata kuliner, wisata belanja, wisata sejarah hingga wisata budaya. Hal ini yang membuat merebaknya penginapan-penginapan atau hotel serta atraksi wisata yang semakin banyak. Sehingga dalam penyelenggaraan wisata halal, Kota Bandung mendapatkan kemudahan dengan kelebihan yang sebelumnya telah ada dan layanan wisata yang ada tinggal menambahkan pelayanan ekstensif seperti pemberian jaminan sertifikasi halal pada produk makanan atau restoran dan layanan wisata halal lainnya.

\section{Introducing Melalui Event Nasional dan Internasional}

Kesiapan Kota Bandung pada penyelenggaraan wisata halal kemudian dilanjutkan dengan upaya paradiplomasi yang diawali dengan aktivitas introducing atau pengenalan yakni dengan memberikan informasi kepada publik mengenai adanya pariwisata halal di Kota Bandung berupa promosi atau mengikuti pameran baik skala lokal maupun internasional. Pada awal 2019, Pemerintah Kota Bandung bersama dengan komunitas Muslim Movement Indonesia (MMI) mengadakan event besar yaitu Tabligh Akbar dan Halal Expo di Stadion Gelora Bandung Lautan Api (GBLA) yang dihadiri oleh lebih dari ratusan ribu orang. Kegiatan tersebut dilakukan dalam rangka mengenalkan produk dan jasa halal yang berupa kuliner, fashion, inspirasi bisnis dan sekaligus pengenalan kembali kepada masyarakat mengenai penyelenggaraan wisata halal di Kota Bandung (Indonesianhalal.co, 2019).

Aktivitas pengenalan wisata halal dilakukan pula oleh institusi pendidikan tinggi di Kota Bandung yakni oleh Institut Teknologi Bandung (ITB) dengan mengadakan seminar nasional, konferensi internasional dan halal product expo pada acara Adiwidya 5 dengan tagline acara "Innovation in Halal Industry towards Indonesia as the World Halal Lifestyle Center" yang dihadiri oleh berbagai pihak mulai dari akademisi, pemerintah, praktisi industri halal dan masyarakat. Pada acara ini juga menjadi awal upaya menjadikan Kota Bandung sebagai kiblat industri wisata halal dunia. Dengan merangkul segala pihak dalam mewujudkan visi tersebut (Pahlevi, 2017). 
Kegiatan internasional yang diikuti oleh Indonesia di acara Malaysia International Halal Showcase 2019 yang menjadi acara tahunan bagi berkumpulnya pegiat industri halal di seluruh dunia dengan memberikan promosi bagi produk halal andalan dari negara masingmasing. Paradiplomasi Kota Bandung ditunjukkan dengan mengirim perwakilan untuk turut hadir bersama dengan pemerintah pusat di dalam mempromosikan Kota Bandung dan Indonesia sebagai destinasi unggulan wisata halal. Pada ajang ini juga menjadi fokus bagi pemerintah untuk melakukan branding dan penjualan produk wisata halal Kota Bandung sekaligus pula mempertahankan eksistensi wisata Indonesia di dunia.

\section{Peningkatan Apresiasi Positif melalui Layanan Wisata Halal}

Aktivitas diplomasi publik yang selanjutnya dilakukan yakni upaya peningkatan apresiasi positif dan penghargaan dari negara lain kepada Kota Bandung. Hal ini diupayakan oleh Kota Bandung melalui pemenuhan layanan dan fasilitas yang memadai serta beautifikasi dari destinasi wisata halal. Pelayanan yang diberikan berupa penyediaan tempat ibadah yang mudah ditemui, produk dengan adanya sertifikasi jaminan halal, hotel syariah maupun hotel yang menyediakan layanan halal, dan paket perjalanan wisata halal. Bandung sebagi kota dengan populasi muslim mayoritas maka dapat ditemukannya masjid-masjid besar maupun kecil dengan mudah di setiap sudut kota. Tempat-tempat perbelanjaan seperti Mal Paris van Java, Mal Trans Studio dan Mal Cihampelas Walk menyediakan mushola yang memadai dan mudah ditemukan. Layanan hotel syariah dan hotel yang menawarkan fasilitas halal pun semakin dapat mudah ditemui seperti Hotel Trans Luxury, Hotel Lingga, Hotel Noor, Hotel Narapati Indah Syariah, Daarul Jannah Cottage. Produk-produk halal di Kota Bandung juga diberikan jaminan sertifikasi halal dari LPPOM-MUI dan BPJPH.

Apresiasi positif yang diterima Kota Bandung dari pelayanan wisata halal pun datang dari berbagai pihak. Penghargaan kepada The Trans Luxury Hotel yang pada tahun 2016 diberikan sebagai Hotel Mewah Terbaik dalam menyediakan layanan pariwisata halal pada acara World Halal Tourism Award di Abu Dhabi. Selain itu pula apresiasi diberikan kepada salah satu turis asal Malaysia atas pengalamannya di salah satu hotel syariah Kota Bandung. Dengan adanya penghargaan tersebut maka wisata halal di Kota Bandung mendapatkan pengakuan di mata internasional dengan pelayanan yang memuaskan dan memiliki keunikan dibandingkan destinasi pariwisata halal lainnya. Selain apresiasi yang didapatkan dari publik global, wisata halal Kota Bandung juga mendapatkan penghargaan dari Kementerian Pariwisata Republik Indonesia sebagai destinasi wisata halal unggulan di Indonesia. Sehingga dengan adanya penghargaan ini menjadi pemacu bagi Pemerintah Kota Bandung untuk terus memberikan layanan terbaiknya dalam pariwisata halal.

Engaging melalui Aktivitas Familiarization Trip

Aktivitas paradiplomasi Kota Bandung dilakukan pula dengan mengadakan Familiarization Trip (Fam Trip) dengan mengundang Kelompok Influencer dari Arab Saudi dan Jurnalis Media Afghanistan untuk datang 
ke Kota Bandung dengan sponsor dari Kementerian Pariwisata Indonesia. Sejak lama kegiatan Fam Trip dilakukan oleh Kementerian Pariwisata guna memenuhi target kunjungan publik global. Fam Trip menjadi salah satu dari empat pilar promosi pariwisata Indonesia ke luar negeri, dimana tiga yang lain mengadakan dan mengikuti event pariwisata internasional, sales mission dan partisipasi festival. Fam Trip merupakan perjalanan wisata yang dilakukan untuk mengenalkan potensi objek wisata di Indonesia dengan mengundang masyarakat dari luar negeri, kelompok masyarakat yang diundang pun dikhususkan yang memiliki pengaruh luas untuk publikasi seperti tokoh masyarakat, artis, public figure, jurnalis, influencer media sosial, atau agen travel.

Strategi Fam Trip dianggap efektif dan efisien dalam mempromosikan pariwisata sehingga hal ini juga diberlakukan kepada penyelenggaraan wisata halal. Kota Bandung melaksanakan Fam Trip dalam rangka mempromosikan wisata halal sebagai langkah engaging dengan publik Arab Saudi dan Afghanistan yang diundang untuk berkunjung ke Bandung. Kelompok influencer dari Arab Saudi tergabung dalam grup Tourism Lovers menjelajahi Bandung selama 4 hari mengunjungi destinasi wisata halal Bandung yang terkenal dan aktivitas belanja kuliner dan pakaian. Kelompok influencer ini juga memiliki anggota yang tersebar di negara-negara Timur Tengah lainnya seperti Mesir, Yordania dan Uni Emirat Arab. Dengan mengundang kelompok influencer ini ke Bandung untuk mengunjungi destinasi wisata halal maka pemerintah berharap akan meningkatnya jumlah kedatangan wisatawan mancanegara dari Arab Saudi dan negara-negara Timur Tengah lainnya. Kelompok influencer ini memiliki pengaruh yang besar di media sosial milik mereka dan memiliki pengikut media sosial yang besar. Sebagian besar masyarakat Arab Saudi juga aktif bersosial media seperti di Instagram, Youtube, dan Facebook. Sehingga kelompok influencer ini diharapkan dapat memberikan pengaruh dan menjadi rujukan bagi masyarakat Arab Saudi ketika menentukan destinasi wisata halal untuk berlibur. Karakteristik wisata di Kota Bandung dikenal cocok dengan karakter wisatawan asal Timur Tengah dikarenakan mereka menyukai keindahan alam yang hijau dan dingin dengan atraksiatraksi yang disediakan. wisata halal di Kota Bandung diharapkan dapat menjadi daya tarik utama publik global untuk berlomba-lomba berkunjung ke Kota Bandung.

Fam Trip mengunjungi wisata halal Kota Bandung juga dilakukan dengan mengundang jurnalis dari Afghanistan. Kedatangan jurnalis ini berasal dari rekomendasi KBRI Kabul yang menyarankan untuk mengundang wartawan dari TOLO dan Ariana Television Network yang merupakan saluran televisi utama dan terbesar di Afghanistan. Kegiatan dilaksanakan di tiga kota yaitu Jakarta, Bogor dan Bandung. Di Kota Bandung, para jurnalis ini ditemani dengan staf dari Kementerian Pariwisata dan Dinas Kebudayaan dan Pariwisata Kota Bandung untuk mengelilingi Gedung Sate, Museum Konferensi Asia Afrika, Tangkuban Perahu, Masjid Agung, Alun-Alun Kota Bandung serta destinasi kuliner lain di Bandung.

Jurnalis dari Afghanistan mengaku memiliki pengalaman yang menyenangkan ketika mengunjungi destinasi wisata halal di Kota 
Bandung, keramahan masyarakat Sunda dan pelayanan wisata yang sangat memuaskan. Para jurnalis ini kemudian meliput perjalanan mereka mengunjungi Kota Bandung dan beberapa kota lainnya untuk ditayangkan di media televisi di Afghanistan. Hal ini juga dapat menjadi sarana promosi wisata halal Kota Bandung dan Indonesia di Afghanistan. Fam Trip dengan mengundang publik global diharapkan dapat menumbuhkan pemahaman masing-masing pihak yang memiliki budaya dan latar belakang yang berbeda. Selain itu dengan adanya Fam Trip, diharapkan mampu menambah kedekatan dan keeratan bagi hubungan antarnegara maupun aktor subnasional.

\section{Influencing dengan Menjalin Kerjasama di Bidang Industri Halal}

Hubungan luar negeri daerah dalam upaya pengembangan kerjasama internasional dilakukan secara intensif oleh Kota Bandung. Salah satu bentuk kesuksesan paradiplomasi Kota Bandung yaitu terjalinnya kerjasama dengan Pemerintah Belgia. Pemerintah Kota Bandung melihat potensi yang prospektif dengan menjalin kerjasama dengan Pemerintah Belgia. Terdapat tiga bidang penjajakan kerjasama yang dilakukan, yaitu kesehatan, industri halal dan industri penerbangan. Kerjasama ini menjadi lanjutan dari Memorandum of Understanding dari kerjasama sister city antara Kota Bandung dengan Kota Namur, Belgia pada 2017.

Kerjasama ini difokuskan pada pengembangan industri halal yang terdiri dari makanan halal, sertifikasi jaminan produk halal dan wisata halal. Belgia menganggap Bandung sebagai kota yang telah memiliki penyelenggaraan wisata halal yang baik dan mampu menjadi role model bagi Belgia dalam upayanya mengembangkan industri wisata halal. Belgia ingin meningkatkan kerjasama yang positif dan konstruktif terutama dalam proses pembuatan makanan halal. Kerjasama ini diharapkan dapat menjadi sarana untuk bertukar pikiran dalam rangka pengolahan dan pembuatan makanan halal. Kerjasama ini dapat menjadi motivasi bagi Kota Bandung untuk menguatkan dalam penggarapan makanan dan wisata halal mengacu pada visi Kota Bandung yang Agamis. Kerjasama yang dilakukan berpotensi memberikan kekuatan bagi Kota Bandung dalam memberikan pengaruhnya di kancah industri halal global. Dengan dimulainya hubungan luar negeri dengan Belgia, diharapkan dapat memunculkan kerjasama lainnya pada bidang industri dan wisata halal. Ketika aktor subnasional memiliki reputasi yang besar dalam suatu bidang dan mendapatkan ajakan untuk kerjasama maka aktor subnasional tersebut telah mendapatkan pengakuan akan kemampuannya di bidang tersebut dan layak untuk menjalin kerjasama.

\section{Kesimpulan}

Tulisan ini mampu menunjukkan bahwa hubungan luar negeri daerah menjadi salah satu hirauan bagi aktor subnasional agar mampu berkiprah dan mendapatkan peluang-peluang dari sumberdaya luar negeri bagi kemajuan pembangunan daerah. Paradiplomasi Kota Bandung terhadap publik global mengenai wisata halal menjadi salah satu bentuk upaya daerah dalam menjalin hubungan luar negeri daerahnya. Tulisan 
ini menemukan bahwa terdapat empat tahapan upaya paradiplomasi Kota Bandung terhadap publik global mengenai wisata halal yang terdiri dari introducting, increasing appreciation, engaging dan influencing. Wisata halal menjadi salah satu tren wisata di Kota Bandung mengingat potensi yang dimiliki pada permintaan terhadap wisata halal dengan meningkatnya populasi muslim di seluruh dunia. Oleh karena itu, upaya Pemerintah Kota Bandung sudah tepat untuk menambah fasilitas wisatanya menuju kepada wisata halal dikarenakan Bandung sudah terkenal sebagai destinasi wisata terbaik di Indonesia serta masyarakat Bandung yang mayoritas muslim sebagai suatu kelebihan yang dimiliki.

Paradiplomasi Kota Bandung mengenai wisata halal dilakukan kepada publik global di ajang eksibisi atau event besar tahunan mengenai industri halal. Paradiplomasi Kota Bandung juga dilakukan untuk mendapatkan apresiasi positif dari publik global dengan memberikan pelayanan wisata halal yang optimal dan lengkap. Langkah engaging di dalam paradiplomasi Kota Bandung dilakukan untuk menambah kedekatan dan keeratan hubungan antaraktor dengan mengadakan Familiarization Trip yang mengundang jurnalis dan kelompok influencer dari Arab Saudi dan Afghanistan. Terakhir yaitu upaya influencing dari paradiplomasi Kota Bandung dengan mengadakan kerjasama internasional dengan Belgia di bidang industri produk dan pariwisata halal. Dengan upaya diplomasi publik yang dilakukan, Kota Bandung berusaha untuk mendapatkan soft power-nya untuk dapat mendatangkan publik global ke Kota Bandung serta memberikan citra positif bagi Kota Bandung sendiri. Paralelitas Aktor yang terlibat dalam menyukseskan wisata halal terdiri dari Penta Helix yaitu akademisi, pelaku industri, masyarakat atau komunitas, pemerintah pusat dan daerah, serta media.

Pemerintah Kota Bandung sebagai aktor subnasional menjalankan atau menyelaraskan kebijakan dari pemerintah pusat terkait hirauan Indonesia terhadap wisata halal. Hal ini tidak terlepas dari isu global yang berkembang dimana isu wisata halal sudah jadi tren negara dunia baik muslim maupun non-muslim. Dalam konteks pembangunan daerah, wisata halal menjadi instrumen agar daerah bisa lebih berdaya dan membangun potensinya dalam konteks pengembangan wisata halal. Hal ini sejalan dari tujuan otonomi daerah dan desentralisasi, yaitu kemandirian ekonomi dan kesejahteraan masyarakat daerah. Dalam hal ini, aktor subnasional bisa memainkan peran penting dalam pelaksanaan pembangunan melalui paradiplomasi. Sehingga aktor subnasional perlu meningkatkan kapasitas dan kapabilitas di dalam melaksanakan hubungan luar negeri.

Sebagai saran, peneliti melihat paradiplomasi kota atau kabupaten di Indonesia belum dilakukan secara optimal. Hubungan luar negeri daerah yang dilakukan masih terbatas pada pelaksanaan sister city antardua kota/ kabupaten atau provinsi di luar negeri. Aktor subnasional di Indonesia masih pasif untuk secara proaktif menggali dan memanfaatkan peluang yang terdapat dari sumber-sumber luar negeri agar dapat dimanfaatkan bagi pembangunan daerah, seperti menarik investor asing ke daerah, mencari hibah luar negeri bagi pembangunan daerah, membuka pasar luar negeri untuk mengenalkan produk unggulan daerah, pemanfaatan 
diaspora warga Kota Bandung dan kegiatan paradiplomasi lainnya. Hal inilah yang perlu dilakukan oleh Pemerintah Kota Bandung disamping pelaksanaan sister city.

\section{Daftar Pustaka}

Adam, M. F. R., Iqbal, M., \& Trihartono, A. (2017). Gastrodiplomacy Jepang di Indonesia Melalui Program Japan Halal Food Project (JHFP) Tahun 20132015. E-SOSPOL, 4(1), pp. 12-19.

Al-Qardhawi, Y. (2013). The Lawful and the Prohibited in Islam. New York: American Trust Publications.

Asdhiana, I. M. (2015) Wisatawan Brunei Paling Suka Melancong ke Bandung [Online], Kompas.com. Tersedia dalam: <https://travel.kompas.com/ $\mathrm{read} / 2015 / 02 / 10 / 114300327 /$ Wisatawan.Brunei.Paling.Suka.Melancong. ke.Bandung $>$ [Diakses 23 Januari 2020].

Bagian Kerjasama Kota Bandung. (2019) Awal Mula dan Sejarah Kerjasama Sister City [Online], Bagian Kerja Sama Kota Bandung. Tersedia dalam: <http:// kerjasama.bandung.go.id/ksln/ksdpl> [Diakses 15 Februari 2020].

Battour, M., \& Ismail, M. N. (2016). Halal tourism: Concepts, Practises, Challenges and Future. Tourism Management Perspectives, 19(B), pp. 150-154.

Cohn, T. H., \& Smith, P. J. (1996). Subnational Governments as International Actors: Constituent Diplomacy in British Columbia and the Pacific Northwest. BC Studies, (110), pp. 25-59.

Deniar, S. M., \& Effendi, T. D. (2019). Halal Food Diplomacy in Japan and South Korea. Journal of Social and Political Sciences, 2(3), pp. 805-813.

Disdagin Kota Bandung. (2019). About Little Bandung [Online], Little Bandung. Tersedia dalam: <https://littlebandung.co.id/latar-belakang/> [Diakses 15 Februari 2020].

Fathun, L. M. (2016). Paradiplomasi Menuju Kota Dunia: Studi Kasus Pemerintah Kota Makassar. Indonesian Perspective, 1(1), pp. 75-94.

Fathun, L. M. (2018). 'Pariwisata di Era Ekonomi Digital' Sebuah Implementasi Pilar Kebijakan Poros Maritim di Era Jokowi dalam Konteks Paradiplomacy. Jurnal Dinamika Ekonomi Pembangunan, 1(2), pp. 56-70.

Fauzi, A. K., Astini, Y., \& Kartika, S. E. (2018). Peran Lembaga Keuangan Syariah dan Hotel dalam Meningkatkan Potensi Wisata Halal Pulau Lombok. Istinbáth: Jurnal Hukum dan Ekonomi Islam, 17(2), pp. 451-475.

Hafizh, M. N. (2019). Raih Penghargaan, Kota Bandung Mantapkan Wisata Halal [Online], Ayobandung.com. Tersedia dalam: <https://www.ayobandung. com/read/2019/04/09/49244/raih-penghargaan-kota-bandung-mantapkanwisata-halal> [Diakses 13 Februari 2020].

Hussin, H. (2018). Gastronomy, Tourism, and the Soft Power of Malaysia. SAGE Journals, 8(4), pp. 1-11.

Indonesianhalal.co. (2019). 'Muslim Movement Indonesia' di Bandung Hadirkan Tabligh Akbar dan Halal Expo [Online], IndonesiaHalal.co. Tersedia dalam: $<$ http://indonesianhalal.co/muslim-movement-indonesia-di-bandunghadirkan-tabligh-akbar-dan-halal-expo/> [Diakses 17 Januari 2020]. 
Isnaeni, H. F. (2019). Menelaah Sejarah Otonomi Daerah [Online], Historia. id. Tersedia dalam: <https://historia.id/politik/articles/menelaah-sejarahotonomi-daerah-Dwg2Z> [Diakses 15 Februari 2020].

Ivanova, P., \& Khalifa, M. (2019). The Role of Non-governmental Organisations in Development Tourism Sector: A Comparative Study Between Bulgaria and Egypt. Central European Journal of International and Security Studies, 13(1), pp. 86-99.

Jo, H. (2016). Mengapa Bandung Dijuluki Parijs van Java? [Online], Historia. id. Tersedia dalam: <https://historia.id/urban/articles/mengapa-bandungdijuluki-parijs-van-java-P4WoZ> [Diakses 14 Januari 2020].

Khoiriati, S. D., Suharko, Krisnajaya, I. M., \& Dinarto, D. (2018). Debating Halal Tourism Between Values and Branding: A Case Study of Lombok, Indonesia. KnE Social Sciences, 3(5), pp. 494-515.

Lachapelle, G., \& Paquin, S. (2005). Why do sub-states and regions practice international relations? In: Paquin, S. \& Lachapelle, G. eds. Mastering Globalization: New Sub-States' Governance and Strategies. London: Routledge, pp. 77-89.

Lecours, A. (2007). Basque Nationalism and The Spanish State. Reno/Las Vegas: University of Nevada Press.

Leonard, M. (2002). Public Diplomacy. London: The Foreign Policy Center.

Lipka, M., \& Hackett, C. (2017). Why Muslims are the world's fastest-growing religious group [Online], Pew Research Center. Tersedia dalam: <https:// www.pewresearch.org/fact-tank/2017/04/06/why-muslims-are-the-worldsfastest-growing-religious-group/> [Diakses 14 Januari 2020].

Mastercard \& HalalTrip. (2017). Muslim Millennial Travel Report 2017 [Online], halaltrip. Tersedia dalam: <https://www.halaltrip.com/halal-travel/muslimmillennial-travel-report//> [Diakses 15 Februari 2020].

Mohsin, A., Ramli, N., \& Alkhulayfi, B. A. (2016). Halal Tourism: Emerging Opportunities. Tourism Management Perspectives, 19(B), pp. 137-143.

Nurdiansyah, A. (2018). Halal Certification and Its Impact on Tourism in Southeast Asia: A Case Study Halal Tourism in Thailand. KnE Social Sciences, 3(5), pp. $26-43$.

Pahlevi, G. A. (2017). Kenalkan Industri Halal, KAMIL Pascasarjana ITB Gelar Adiwidya 5 [Online], Institut Teknologi Bandung. Tersedia dalam: <https:// www.itb.ac.id/news/read/56434/home/kenalkan-industri-halal-kamilpascasarjana-itb-gelar-adiwidya-5> [Diakses 19 Februari 2020].

PPID Kota Bandung (2016) Geografis dan Sejarah Kota Bandung [Online], Pejabat Pengelola Informasi dan Dokumentasi Kota Bandung. Tersedia dalam: <https://ppid.bandung.go.id/knowledgebase/sejarah-kota-bandung/> [Diakses 16 Februari 2020].

Pratiwi, S. R., Dida, S., \& Sjafirah, N. A. (2018). Strategi Komunikasi dalam Membangun Awareness Wisata Halal di Kota Bandung. Jurnal Kajian Komunikasi, 6(1), pp. 78-90. 
Radd. (2016). Bentuk EHTC, STP Bandung Siap Genjot Wisata Halal [Online], BeritaSatu. Tersedia dalam: $<$ https://www.beritasatu.com/food-travel/375917bentuk-ehtc-stp-bandung-siap-genjot-wisata-halal.html> [Diakses 6 Februari 2020].

Samori, Z., Md Salleh, N. Z., \& Khalid, M. M. (2016). Current trends on Halal Tourism: Cases on selected Asian countries. Tourism Management Perspectives, 19 (B), pp. 131-136.

Satriana, E. D., \& Faridah, H. D. (2018). Wisata Halal: Perkembangan, Peluang, dan Tantangan. Journal of Halal Product and Research (JHPR), 1(2), pp. 32-43.

Subarkah, A. R. (2018). Diplomasi Pariwisata Halal Nusa Tenggara Barat. Intermestic: Journal of International Studies, 2(2), pp. 188-203.

Vargas-Sánchez, A., \& Perano, M. (2018). Halal Tourism through the Lens of Generation Z in a Muslim Majority Country: Implications on Tourist Services. International Journal of Business and Management, 13(9), pp. 36-49.

Wibyaninggar, S. A., \& Aminah, S. (2018). Halal tourism as Japan's Economic and Diplomatic Strategy. In: Adi \& Achwan. eds. Competition and Cooperation in Social and Political Sciences. London: Routledge, pp. 149-155. 